\title{
Serum macrophage migration inhibitory factor (MIF) levels after allogeneic hematopoietic stem cell transplantation
}

T. TOUBAI*, ${ }^{*}$, Y. SHONO* , J. NISHIHIRA ${ }^{\ddagger}$, M. IBATA* ${ }^{*}$ J. SUIGITA*, N. KATO*, T. OHKAWARA ${ }^{\ddagger}$, S. TONE ${ }^{\ddagger}$ K. P. LOWLER ${ }^{\dagger}$, S. OTA ${ }^{\S}$, J. TANAKA*, M. ASAKA ${ }^{\S}$, P. REDDY ${ }^{\dagger}$, M. IMAMURA*

*Department of Hematology and Oncology, Hokkaido University Graduate School of Medicine, Sapporo, Japan

${ }^{\dagger}$ Blood and marrow stem cell transplantation program, University of Michigan Cancer Center, Ann Arbor, MI, USA

${ }^{\ddagger}$ Department of Research and Development, GeneticLab Co. Ltd, Sapporo, Japan

\$Department of Gastroenterology and Hematology, Hokkaido University Graduate School of Medicine, Sapporo, Japan

Correspondence:

Dr Tomomi Toubai, Department of Internal Medicine, Blood and Marrow stem cell transplantation program, University of Michigan Comprehensive Cancer Center, 1500 E Medical Center Drive, 6410 CGC, Ann Arbor, MI 48109-0942,

USA. Tel.: (734) 615 3340;

Fax: (734) 647 9271;

E-mail: ttoubai@hkg.odn.ne.jp; tomomit@umich.edu

doi:10.1111/j.1751-553X.2007.01016.X

Received 11 June 2007; accepted for publication 9 October 2007

Keywords

Macrophage migration inhibitory factor, acute graft-versus-host-disease, chronic graft-versus-host-disease, allogeneic stem cell transplantation

\section{SUMMARY}

Macrophage migration inhibitory factor (MIF) may play an important role in the pathogenesis of acute graft-versus-host disease (aGVHD) after allogeneic hematopoietic stem cell transplantation (allo-HSCT), as MIF plays an important role to regulate the production of tumor necrosis factor- $\alpha(\mathrm{TNF}-\alpha)$, one of the inflammatory cytokines which induces and exacerbates aGVHD. We examined the association between serum MIF levels and aGVHD vs. chronic GVHD (cGVHD) in allo-SCT patients in this study. We found a significant increase in the peak serum MIF $(14.46 \mathrm{ng} \pm 1.47 \mathrm{ng} / \mathrm{ml})$ at onset in patients that developed aGVHD $(n=23, P=0.009)$. We also found that mean serum MIF levels in patients who developed extensive type cGVHD within 6 months $(12.58 \pm 2.18 \mathrm{ng} / \mathrm{ml}, n=13)$ were significantly higher than MIF levels before allo-HSCT $(7.86 \pm 1.17 \mathrm{ng} / \mathrm{ml}, n=19$, $P=0.04)$. Therefore, we speculated that serum MIF levels increase during the active phase of both aGVHD and cGVHD. 


\section{INTRODUCTION}

Allogeneic hematopoietic stem cell transplantation (allo-HSCT) is an important curative therapy for hematological malignancies. However, acute graft-versus-host disease (aGVHD) has been a major complication after allo-HSCT (Ferrara \& Deeg, 1991). The pathophysiology of aGVHD is a complex process which can be conceptualized as a three-step process: conditioning effect phase, T-cell activation phase, and cellular and inflammatory effector phase (Ferrara, Cooke \& Teshima, 2003; Reddy \& Ferrara, 2003). Moreover, the activation and expansion of donor $\mathrm{T}$ cells leads to the secretion of proinflammatory cytokines and the recruitment of additional inflammatory effector cells to several target organs (gut, liver, and skin). This induces further damage to the affected tissues (Shlomchik et al., 1999; Hill \& Ferrara, 2000). In contrast, chronic GVHD (cGVHD) is a complex multiorgan disorder with features of autoimmunity and immunodeficiency (Graze \& Gale, 1979; Shulman et al., 1980) and it remains to be the major cause of late death and morbidity after allo-HSCT (Socie et al., 1999; Baker et al., 2004).

Macrophage migration inhibitory factor (MIF) was originally discovered as a lymphokine reported to prevent the random migration of macrophages, recruiting them instead to sites of inflammation (Bloom \& Bennett, 1966; David, 1966). Recent studies have revealed that MIF is ubiquitously expressed in various types of cells, especially $\mathrm{T}$ cells and macrophages, and has been re-evaluated as a pluripotent cytokine involved in broad-spectrum control of the immune system (Bucala, 1996; Nishihira, 2000). It has also been shown to be a proinflammatory cytokine and pituitary-derived hormone which potentiates endotoxemia (Bernhagen et al., 1993). Subsequent work showed that $\mathrm{T}$ cells and macrophages secrete MIF in response to glucocorticoids as well as upon activation by various pro-inflammatory stimuli (Calandra et al., 1994). Moreover, it has been suggested that tumor necrosis factor- $\alpha$ (TNF- $\alpha)$ and interferon gamma (IFN- $\gamma$ ) upregulate MIF production in macrophages and that, conversely, MIF induces TNF- $\alpha$ production, forming a proinflammatory loop within the cytokine network (Calandra et al., 1994). Furthermore, anti-MIF antibodies inhibit T-cell proliferation and IL-2 production in vitro and suppress antigen-driven $\mathrm{T}$-cell activation and antibody production in vivo (Bacher et al., 1996). MIF therefore plays an important role in the pathogenesis of inflammatory diseases. The serum level and the local expression level of MIF are significantly increased in inflammatory diseases such as rheumatoid arthritis (Onodera et al., 1999), acute pulmonary diseases (Donnelly et al., 1997), glomerulonephritis (Lan et al., 2000), focal glomerular sclerosis (Matsumoto et al., 2005), systemic sclerosis (Selvi et al., 2003), chronic colitis, and experimental colitis (de Jong et al., 2001; Ohkawara et al., 2002). Recent studies have shown local MIF expression to be up-regulated in the allo-immune reaction during renal transplantation and bone marrow (BM) transplantation. It also co-localizes with macrophage and T-cell infiltration (Lan et al., 1998; Brown et al., 1999; Lo et al., 2002; Jose et al., 2003; Toubai et al., 2006). We found an association between local MIF expression and aGVHD in murine models using MIF knock out mice (Toubai et al., 2006). The aGVHD scores and pathological findings in this study showed that MIF-deficient lymphocytes do not induce severe aGVHD (Toubai et al., 2006). These observations suggest that MIF may also play an important role in the pathogenesis of aGVHD after allo-HSCT. We therefore set out to determine whether or not serum MIF has an influence on aGVHD and CGVHD outcome after allo-HSCT.

\section{PATIENTS AND METHODS}

\section{Patients' characteristics}

Archived specimen samples from 45 consecutive patients undergoing HSCT from January 2000 to June 2005 at Hokkaido University Hospital, Sapporo, were studied. All the patients were informed of, and consented to, sample collection and usage. Their clinical characteristics are shown in Table 1. The 45 patients included 24 males and 21 females with the median age of 37 (range, 16-65) years. Primary diseases were 13 chronic myelogenous leukemia, nine acute myelogenous leukemia (AML), nine myelodysplastic syndrome (MDS), six acute lymphoblastic leukemia, four non-Hodgkin lymphoma (NHL), two adult T-cell leukemia (ATL), one multiple myeloma and one aplastic anemia. We defined the risk as follows: 1) standard risk: AML 1st and 2nd CML, MDS refractory anemia (RA), NHL 1st CR, 2) high risk: AML 3rd CR, non-CR, 


\begin{tabular}{|c|c|}
\hline No of patients & 45 \\
\hline \multicolumn{2}{|l|}{ Sex } \\
\hline Male & 25 \\
\hline Female & 20 \\
\hline Median age (range) & $37(16-65)$ \\
\hline \multicolumn{2}{|l|}{ Underlying diagnosis } \\
\hline CML (12 chronic phase, one blastic crisis) & 13 \\
\hline AML & 9 \\
\hline MDS & 9 \\
\hline ALL & 6 \\
\hline NHL & 4 \\
\hline ATL & 2 \\
\hline MM & 1 \\
\hline AA & 1 \\
\hline \multicolumn{2}{|l|}{ Risk } \\
\hline $\begin{array}{l}\text { Standard risk (AML 2nd CR, MDS RA, } \\
\text { CML } 1 \text { chronic phase (CP), NHL } 1 \mathrm{CR} \text { ) }\end{array}$ & 33 \\
\hline $\begin{array}{l}\text { High risk (AML 3rd CR, NCR, MDS } \\
\text { RAEB-t and overt leukemia, MM PR, } \\
\text { NHL PR, NCR, CML blastic crisis (BC), } \\
\text { ATL PR) }\end{array}$ & 11 \\
\hline \multicolumn{2}{|l|}{ Source of stem cells } \\
\hline Peripheral blood stem cell & 4 \\
\hline Bone marrow & 37 \\
\hline Cord blood & 4 \\
\hline \multicolumn{2}{|l|}{ Human leukocyte antigen (HLA) } \\
\hline HLA-identical siblings & 15 \\
\hline HLA-1 locus mismatch siblings & 2 \\
\hline Matched-unrelated donors & 22 \\
\hline HLA-1 locus mismatched unrelated donors & 2 \\
\hline Others & 4 \\
\hline \multicolumn{2}{|l|}{ Conditioning regimen } \\
\hline CST & 31 \\
\hline RIST & 14 \\
\hline \multicolumn{2}{|l|}{ GVHD prophylaxis } \\
\hline Cyclosporin \pm short term MTX & 30 \\
\hline FK506 + short term MTX & 15 \\
\hline \multicolumn{2}{|l|}{ aGVHD (overall grade) } \\
\hline None & 12 \\
\hline Gradel & 10 \\
\hline Grade 2 & 16 \\
\hline Grade 3 & 5 \\
\hline Grade 4 & 2 \\
\hline \multicolumn{2}{|l|}{ cGVHD } \\
\hline None & 17 \\
\hline Limited type & 5 \\
\hline
\end{tabular}

MDS refractory anemia with excess of blasts in transformation (RAEB-t) and overt leukemia, multiple myeloma partial remission (PR), NHL PR, non complete remission (NCR), ATL PR. Conditioning regimens
Table 1. (Continued)

Extensive type

Not evaluated

19

4

CML, chronic myelogenous leukemia; AML, acute myelogenous leukemia; MDS, myelodysplastic syndrome; ALL, acute lymphoblastic leukemia; NHL, non-Hodgkin lymphoma; ATL, adult T-cell leukemia; MM, multiple myeloma; AA, aplastic anemia; RA, refractory anemia; $\mathrm{PR}$, partial remission; CST, conventional stem cell transplantation; RIST, reduced intensity stem cell transplantation; MTX, methotrexate; aGVHD, acute graft-versus-host disease; cGVHD, chronic graft-versus-host disease.

were either conventional myeloablative conditioning or reduced intensity conditioning (69 and 31\%, respectively). Prophylaxis of GVHD included cyclosporin \pm short term methotrexate (sMTX) for 30 cases and FK506 + sMTX for 15 cases. Acute GVHD grade and chronic GVHD grades were $0(n=12), 1(n=10), 2$ $(n=16), 3(n=5), 4(n=2)$ and none $(n=17)$, limited type $(n=5)$, extensive type $(n=19)$ and not evaluate $(n=4)$, respectively.

\section{Assay for human serum MIF by enzyme-linked immunosorbent assay}

MIF was measured in serum collected before and at time points 1 month, 3 months, 6 months, and 1 year after allo-HSCT. We described this in detail in our previous reports (Ohkawara et al., 2002). Serum MIF concentrations were measured by enzyme-linked immunosorbent assay (ELISA) specific for MIF. An anti-human MIF IgG polyclonal antibody dissolved in $50 \mu \mathrm{l}$ of phosphate-buffered saline (PBS) was added to each well of a 96-well microtiter plate and left for $30 \mathrm{~min}$ at room temperature. After the plate had been washed thrice with distilled water, all wells were filled with PBS containing $0.5 \%$ bovine serum albumin to block nonspecific blocking and left for $20 \mathrm{~min}$ at room temperature. After removal of the blocking solution, serum samples were added in duplicate to individual wells and incubated for $1 \mathrm{~h}$ at room temperature. After the plate was washed thrice with PBS containing $0.05 \%$ Tween-20 (washing buffer), $50 \mu \mathrm{l}$ of biotin-conjugated anti-MIF antibody was added to each well. After incubation for $1 \mathrm{~h}$ at 
room temperature, the plate was again washed thrice with washing buffer. Then avidin-conjugated antihuman IgG antibody was added to each well, and incubated $15 \mathrm{~min}$ at room temperature. After washing thrice with the washing buffer, the substrate solution $(50 \mu \mathrm{l})$ was added to each well. This substrate solution $(10 \mathrm{ml})$ contains $8 \mathrm{mg}$ of $o$-phenylenediamine and $4 \mu \mathrm{l}$ of $30 \% \mathrm{H}_{2} \mathrm{O}_{2}$ in citrate phosphate buffer ( $\mathrm{pH}$ 5.0). After incubation for $20 \mathrm{~min}$ at room temperature, the reaction was terminated with $25 \mu \mathrm{l}$ of $4 \mathrm{~N}$ sulfuric acid. The absorbance was measured at $492 \mathrm{~nm}$ by an ELISA plate reader (Model 3550; Biorad, Hercules, CA, USA).

\section{Statistical analysis}

Differences between groups were analyzed by Student's $t$-test. Survival curves were plotted according to the method of Kaplan and Meier, and comparison of the curves was performed using the log-rank test.

\section{RESULTS}

We examined the association between pre-allo-HSCT MIF levels and clinical characteristics. The mean serum MIF levels were $10.0 \pm 1.06 \mathrm{ng} / \mathrm{ml}$. There was no correlation between the pre-allo-HSCT MIF levels

Table 2. Serum MIF levels in patients along with the time course of HSCT by clinical characteristics

\begin{tabular}{|c|c|c|c|c|c|c|c|c|c|}
\hline \multirow[b]{2}{*}{ Variable } & \multicolumn{3}{|l|}{1 month } & \multicolumn{3}{|l|}{3 months } & \multicolumn{3}{|c|}{6 months } \\
\hline & Number & $\begin{array}{l}\text { Pre-MIF } \\
\text { levels }( \pm S E)\end{array}$ & $P$-value & Number & $\begin{array}{l}\text { Pre-MIF } \\
\text { levels }( \pm S E)\end{array}$ & $P$-value & Number & $\begin{array}{l}\text { Pre-MIF } \\
\text { levels }( \pm S E)\end{array}$ & $P$-value \\
\hline Mean & 44 & $9.55 \pm 0.95$ & - & 38 & $9.54 \pm 0.86$ & - & 23 & $11.78 \pm 1.73$ & - \\
\hline \multicolumn{10}{|l|}{ Sex } \\
\hline Male & 25 & $9.65 \pm 1.38$ & \multirow[t]{2}{*}{0.91} & 22 & $9.98 \pm 1.10$ & \multirow[t]{2}{*}{0.56} & 14 & $13.44 \pm 2.59$ & \multirow[t]{2}{*}{0.24} \\
\hline Female & 19 & $9.43 \pm 1.29$ & & 16 & $8.94 \pm 1.41$ & & 9 & $9.21 \pm 1.71$ & \\
\hline \multicolumn{10}{|l|}{ Age (years) } \\
\hline$<40$ & 25 & $9.92 \pm 1.23$ & \multirow[t]{2}{*}{0.67} & 23 & $8.66 \pm 1.05$ & \multirow[t]{2}{*}{0.22} & 13 & $11.62 \pm 2.36$ & \multirow[t]{2}{*}{0.92} \\
\hline$\geqq 40$ & 19 & $9.07 \pm 1.52$ & & 15 & $10.91 \pm 1.46$ & & 10 & $11.99 \pm 2.71$ & \\
\hline \multicolumn{10}{|l|}{ Risk } \\
\hline Standard risk & 32 & $10.11 \pm 1.22$ & \multirow[t]{2}{*}{0.23} & 30 & $9.66 \pm 1.03$ & \multirow[t]{2}{*}{0.78} & 18 & $11.04 \pm 1.67$ & \multirow[t]{2}{*}{0.59} \\
\hline High risk & 11 & $7.90 \pm 1.34$ & & 8 & $9.13 \pm 1.52$ & & 5 & $14.44 \pm 5.61$ & \\
\hline \multicolumn{10}{|c|}{ Source of stem cells } \\
\hline PBSC & 4 & $7.63 \pm 1.67$ & \multirow{3}{*}{0.69} & 3 & $7.13 \pm 2.53$ & \multirow{3}{*}{0.63} & 2 & $15.30 \pm 4.20$ & \multirow[t]{3}{*}{0.40} \\
\hline $\mathrm{BM}$ & 36 & $10.06 \pm 1.09$ & & 32 & $9.68 \pm 0.98$ & & 19 & $12.03 \pm 2.02$ & \\
\hline $\mathrm{CB}$ & 4 & $6.95 \pm 3.20$ & & 3 & $10.57 \pm 2.65$ & & 2 & $5.90 \pm 1.20$ & \\
\hline \multicolumn{10}{|c|}{ Conditioning regimen } \\
\hline CST & 31 & $10.15 \pm 1.26$ & \multirow[t]{2}{*}{0.24} & 28 & $10.15 \pm 1.08$ & \multirow[t]{2}{*}{0.16} & 17 & $11.58 \pm 2.08$ & \multirow[t]{2}{*}{0.85} \\
\hline RIST & 13 & $8.13 \pm 1.11$ & & 10 & $7.84 \pm 1.19$ & & 6 & $12.35 \pm 3.40$ & \\
\hline \multicolumn{10}{|l|}{ GVHD prophylaxis } \\
\hline CyA+ sMTX & 30 & $9.48 \pm 1.26$ & \multirow[t]{2}{*}{0.91} & 28 & $8.98 \pm 0.95$ & \multirow[t]{2}{*}{0.33} & 18 & $11.76 \pm 2.04$ & \multirow[t]{2}{*}{0.98} \\
\hline FK506 + sMTX & 14 & $9.70 \pm 1.35$ & & 10 & $11.14 \pm 1.92$ & & 5 & $11.88 \pm 3.61$ & \\
\hline \multicolumn{10}{|c|}{ aGVHD (overall grade) } \\
\hline Grade 0-1 & 21 & $9.05 \pm 1.38$ & \multirow[t]{2}{*}{0.62} & 17 & $9.37 \pm 1.34$ & 0.86 & 8 & $11.30 \pm 2.90$ & 0.84 \\
\hline Grade $2-4$ & 23 & $10.00 \pm 1.33$ & & 21 & $9.69 \pm 1.15$ & & 15 & $12.04 \pm 2.24$ & \\
\hline cGVHD & & & & & & & & & \\
\hline None & 17 & $10.01 \pm 1.32$ & 0.62 & 14 & $11.02 \pm 1.48$ & 0.59 & 7 & $9.78 \pm 1.19$ & 0.006 \\
\hline Limited type & 5 & $11.02 \pm 3.48$ & & 5 & $9.74 \pm 3.45$ & & 2 & $2.35 \pm 1.65$ & \\
\hline Extensive type & 19 & $9.55 \pm 1.71$ & & 17 & $8.43 \pm 1.11$ & & 13 & $12.57 \pm 2.18$ & \\
\hline
\end{tabular}

MIF, macrophage migration inhibitory factor; HSCT, hematopoietic stem cell transplantation; PBSC, peripheral blood stem cells; BM, bone marrow; CB, cord blood; CST, conventional stem cell transplantation; RIST, reduced intensity stem cell transplantation; MTX, methotrexate; aGVHD, acute graft-versus-host disease; cGVHD, chronic graft-versushost disease. 
and sex, age, risk, aGVHD, or cGVHD grades (data not shown).

Table 2 shows serum MIF levels in patients along the time course of allo-HSCT by clinical characteristics. Mean values were $9.55 \pm 1.06 \mathrm{ng} / \mathrm{ml}(n=44)$ at 1 month, $9.54 \pm 0.86 \mathrm{ng} / \mathrm{ml} \quad(n=38)$ at 3 months, $11.78 \pm 1.73 \mathrm{ng} / \mathrm{ml} \quad(n=23) \quad$ at 6 months and $8.06 \pm 4.74 \mathrm{ng} / \mathrm{ml}(n=12)$ at 1 year. We could not

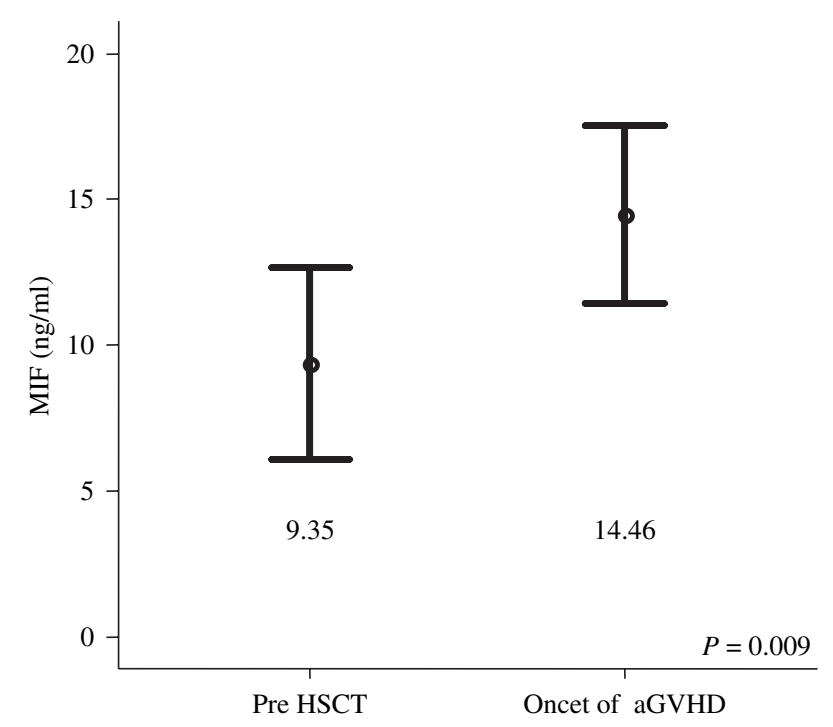

Figure 1. Comparison of before and after hematopoietic stem cell transplantation serum macrophage migration inhibitory factor levels in patients with acute graft-versus-host disease $(n=23)$. find significant differences associating either sex, age, risk, source of stem cells, conditioning regimen, GVHD prophylaxis, or aGVHD grade with serum MIF levels. However, patients who developed a GVHD displayed significant increases in the peak serum MIF at onset $(14.46 \mathrm{ng} \pm 1.47 \mathrm{ng} / \mathrm{ml}) \quad(n=23, P=0.009)$. Figure 1 shows the relationship between onset of aGVHD and peak serum MIF in 23 patients in the aGVHD group.

We also examined the association between serum MIF levels and cGVHD. Although we compared the mean serum MIF levels among the three subgroups at pretransplant and 6 months, we could not find significance differences among these groups. However, we did find significant differences in levels for patients who developed extensive type cGVHD. Mean serum MIF at 6 months $(12.57 \pm 2.18 \mathrm{ng} / \mathrm{ml}, n=13)$ were significantly higher than those before allo-HSCT (7.86 \pm $1.17 \mathrm{ng} / \mathrm{ml}, n=19, P=0.04$ ) (Figure 2). Therefore, we speculated that serum MIF levels increase during the active phase of both aGVHD and cGVHD.

Moreover, although we examined the association between the serum MIF levels in patients and the survival rates, we could not find significance difference.

\section{DISCUSSION}

The present study demonstrated that serum MIF levels after allo-HSCT was associated with aGVHD and an extensive type of cGVHD. Strikingly, increased serum MIF levels preceded the onset of aGVHD, and, as we
Figure 2. The change of serum macrophage migration inhibitory factor levels in chronic graft-versus-host disease (GVHD) patients. These results are represented by solid and dot line by symbols: none of chronic GVHD $(\boldsymbol{\Delta})$, limited type $(\bullet)$, extensive type

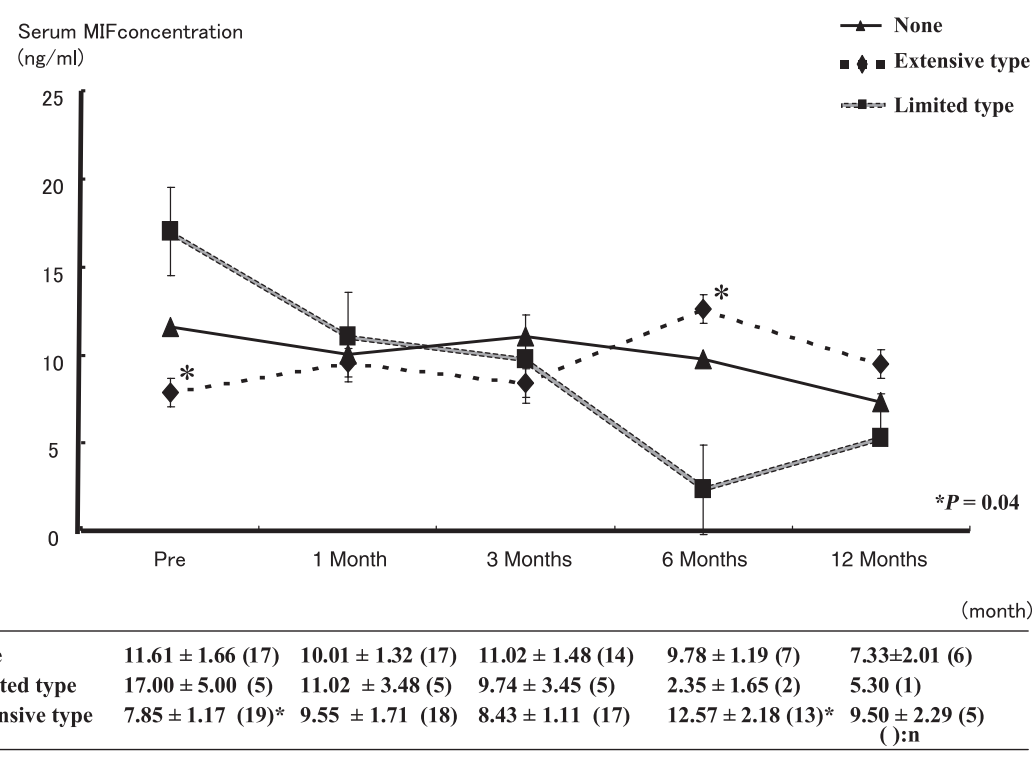


had speculated, displayed a causal relationship between MIF and aGVHD. However, we could not find clear association between serum MIF levels after allo-HSCT and survival rate.

Lo et al., (2002) reported that dramatic increase in local MIF expression in aGVHD is associated with infiltration of activated $\mathrm{T}$ cells and macrophages in alloHSCT in humans. Moreover, they reported that serum MIF levels of aGVHD patients at the onset of clinical aGVHD were increased at least two to fourfolds, when compared with those of allo-HSCT patients without aGVHD (Lo et al., 2002). Although we could not find a clearly significant difference, serum MIF levels were increased in the same patients before and after the onset of aGVHD. So far, there have been no reports that examined the association of serum MIF levels and cGVHD. We have found for the first time that increased serum MIF levels is associated with extensive type cGVHD. These facts led to the speculation that MIF is an important effector cytokine in aGVHD and cGVHD.

We examined the role of MIF in aGVHD after HSCT using MIF KO mice as recipients in our previous study (Toubai et al., 2006). We found that MIF had no significant effect on aGVHD in MIF KO recipient mice and serum MIF levels in MIF KO recipient mice after allo-HSCT was not at all affected by the development of a GVHD. However, significantly lower a GVHD score were seen in the experiment using MIF KO mice as the donors, when we compared the recipient mice transplanted with BM and spleen cells (SP) from MIF KO mice with those of the recipient mice transplanted with BM and SP from WT-BALB/c mice. These results indicated that MIF-deficient lymphocytes did not induce severe aGVHD, suggesting a possible abrogating effect of MIF on the development of aGVHD. However, we could not find any significant differences between survival rates and serum MIF levels associated with aGVHD in previous report. Although we could not explain this finding, we speculated that serum MIF levels may reflect outcomes of aGVHD and cGVHD in humans very well.

Macrophage migration inhibitory factor stimulates macrophage release of proinflammatory cytokines such as TNF- $\alpha$, interleukin $1 \beta$ (IL-1 $\beta$ ), IL-6, and IL-8 (Calandra et al., 1995; Donnelly et al., 1997). MIF is known to be a potent angiogenic factor with proinflammatory effects on the recruitment of human peripheral blood monocytes via the up-regulation of adhesion molecules [vascular cell adhesion molecule1 (VCAM-1) and intercellular adhesion molecule-1 (ICAM-1)] (Asif Amin et al., 2006). Therefore, MIF and its signaling pathways may be potential targets in MN-dependent inflammatory diseases such as RA and atherosclerosis (Asif Amin et al., 2006).

Macrophage migration inhibitory factor plays a vital role in the effector stage of autoimmune injury initiated by type 1 helper (Thl) cells (Bernhagen et al., 1996; Lan et al., 1997; Selvi et al., 2003). aGVHD is similarly dependent on donor-specific cytokine-secreting $\mathrm{T}$ cells (Ferrara, Cooke $\delta$ Teshima, 2003). Serum MIF levels at the onset of aGVHD were increased at least twofold compared with the levels before alloHSCT. It has been reported that intrinsic skin and colon cells are the major sites of MIF production in aGVHD. These findings suggest that MIF might play a role in aGVHD.

Our study results have important therapeutic implications. The observation that MIF is increased in association with aGVHD and CGVHD suggests that its inactivation may be explored as a target of anti-GVHD therapy. Functional studies using anti-MIF antibody in an experimental model of aGVHD may be helpful in defining its role in the treatment of aGVHD.

\section{ACKNOWLEDGEMENTS}

We thank Ms M. Yamane, Ms M. Mayanagi, and Ms Y. Ishimaru for their technical assistance.

\section{REFERENCES}

Asif Amin M., Haas C.H., Zhu K., Mansfield P.J., Kim M.J., Lackowski N.P. \& Koch A.E. (2006) Migration inhibitory factor up-regulates vascular cell adhe- sion molecule-1 and intercellular adhesion molecule-1 via Src, PI3 linase, and NFkB. Blood 107, 2252-2261.

Bacher M., Metz C.N., Calandra T., Mayer K., Chesney J., Lohoff M., Gemsa D., Donnelly T. \& Bucala R. (1996) An essential regulatory role for macrophage migration inhibitory factor in $\mathrm{T}$ cell activation. Proceedings of the National Academy of Sciences of the United States of America 93, 7849-7854. 
Baker K.S., Gurney J.G., Ness K.K., Bhatia R., Forman S.J., Francisco L., McGlave P.B., Robison L.L., Snyder D.S., Weisdorf D.J. \& Bhatia S. (2004) Late effects in survivors of chronic myeloid leukemia treated with hematopoietic cell transplantation: results from the Bone Marrow Transplant Survivor Study. Blood 104, 1898-1906.

Bernhagen J., Calandra T., Mitchell R.A., Martin S.B., Tracey K.J., Voelter W., Manogue K.R., Cerami A. \& Bucala R. (1993) MIF is a pituitary-derived cytokine that potentiates lethal endotoxaemia. Nature 365, 756-759.

Bernhagen J., Bacher M., Calandra T., Metz C.N., Doty S.B., Donnelly T. \& Bucala R. (1996) An essential role for macrophage migration inhibitory factor in the tuberculin delayed-type hypersensitivity reaction. The Journal of Experimental Medicine 183, 277-282.

Bloom B.R. \& Bennett B. (1966) Mechanism of a reaction in vitro associated with delayed-type hypersensitivity. Science 153, 80-82.

Brown F.G., Nikolic-Paterson D.J., Metz C., Bucala R., Atkins R.C. \& Lan H.Y. (1999) Up-regulation of macrophage migration inhibitory factor in acute renal allograft rejection in the rat. Clinical and Experimental Immunology 118 , 329-336.

Bucala R. (1996) MIF rediscovered: cytokine, pituitary hormone, and glucocorticoid-induced regulator of the immune response. The FASEB Journal 10, 16071613.

Calandra T., Bernhagen J., Mitchell R.A. \& Bucala R. (1994) The macrophage is an important and previously unrecognized source of macrophage migration inhibitory factor. The Journal of Experimental Medicine 179, 1895-1902.

Calandra T., Bernhagen J., Metz C.N., Spiegel L.A., Bacher M., Donnelly T., Cerami A. \& Bucala R. (1995) MIF as a glucocorticoid-induces modulator of cytokine production. Nature 377, 6871.

David J.R. (1966) Delayed hypersensitivity in vitro: its mediation by cell-free substances formed by lymphoid cellantigen interaction. Proceedings of the National Academy of Sciences of the United States of America 56, 72-77.

Donnelly S.C., Haslett C., Reid P.T., Grant I.S., Wallace W.A., Metz C.N., Bruce L.J. \& Bucala R. (1997) Regulatory role for macrophage migration inhibitory factor in acute respiratory distress syndrome. Nature Medicine 3, 320-323.

Ferrara J.L., Cooke K.R. \& Teshima T. (2003) The pathophysiology of acute graft-versus-host disease. International Journal of Hematology 78, 181-187.

Ferrara J.L. \& Deeg H.J. (1991) Graft-versus-host disease. New England Journal of Medicine 324, 667-674.

Graze P.R. \& Gale R.P. (1979) Chronic graft versus host disease: a syndrome of disordered immunity. The American Journal of Medicine 66, 611-620.

Hill G.R. \& Ferrara J.L. (2000) The primacy of the gastrointestinal tract as a target organ of acute graft-versus- host disease: rationale for the use of cytokine shields in allogeneic bone marrow transplantation. Blood 95, 2754-2759.

de Jong Y.P., Abadia-Molina A.C., Satoskar A.R., Clarke K., Rietdijk S.T., Faubion W.A., Mizoguchi E., Metz C.N., Alsahli M., ten Hove T., Keates A.C., Lubetsky J.B., Farrell R.J., Michetti P., van Deventer S.J., Lolis E., David J.R., Bhan A.K. \& Terhorst C. (2001) Development of chronic colitis is dependent on the cytokine MIF. Nature Immunology 2, 1061-1066.

Jose M.D., David J.R., Atkins R.C. \& Chadban S.J. (2003) Blockade of macrophage migration inhibitory factor does not prevent acute renal allograft rejection. American Journal of Transplantation 3, 1099-1106.

Lan H.Y., Bacher M., Yang N., Mu W., Nikolic-Paterson D.J., Metz C., Meinhardt A., Bucala R. \& Atkins R.C. (1997) The pathogenic role of macrophage migration inhibitory factor in immunologically induced kidney disease in the rat. The Journal of Experimental Medicine 185, 1455-1465.

Lan H.Y., Yang N., Brown F.G., Isbel N.M., Nikolic-Paterson D.J., $\mathrm{Mu}$ W., Metz C.N., Bacher M., Atkins R.C. \& Bucala R. (1998) Macrophage migration inhibitory factor expression in human renal allograft rejection. Transplantation $66,1465-1471$.

Lan H.Y., Yang N., Nikolic-Paterson D.J., Yu X.Q., Mu W., Isbel N.M., Metz C.N., Bucala R. \& Atkins R.C. (2000) Expression of macrophage migration inhibitory factor in human glomerulonephritis. Kidney International 57, 499-509.

Lo J.W., Leung A.Y., Huang X.R., Lie A.K., Metz C., Bucala R., Liang R. \&
Lan H.Y. (2002) Macrophage migration inhibitory factor (MIF) expression in acute graft-versus-host disease (GVHD) in allogeneic hematopoietic stem cell transplant recipients. Bone Marrow Transplantation 30, 375-380.

Matsumoto K., Maruyama N., Maruyama T., Ohnishi Y., Nonaka S., Inoshita A., Ito K., Kitajima S., Abe M., Satomura A. \& Fujita T. (2005) Elevated macrophage migration inhibitory factor (MIF) levels in the urine of patients with focal glomerular sclerosis. Clinical and Experimental Immunology 139, 338-347.

Nishihira J. (2000) Macrophage migrataion inhibitory factor (MIF): its essential role in the immune system and cell growth. Journal of Interferon and Cytokine Research 20, 751-762.

Ohkawara T., Nishihira J., Takeda H., Hige S., Kato M., Sugiyama T., Iwanaga T., Nakamura H., Mizue Y. \& Asaka M. (2002) Amelioration of dextran sulfate sodium-induced colitis by anti-macrophage migration inhibitory factor antibody in mice. Gastroenterology 123, 256-270.

Onodera S., Tanji H., Suzuki K., Kaneda K., Mizue Y., Sagawa A. \& Nishihira J. (1999) High expression of macrophage migration inhibitory factor in the synovial tissues of rheumatoid joints. Cytokine 11, 163-167.

Reddy P. \& Ferrara J.L. (2003) Immunobiology of acute graft-versus-host disease. Blood Reviews 17, 187-194.

Selvi E., Tripodi S.A., Catenaccio M., Lorenzini S., Chindamo D., Manganelli S., Romagnoli R., Ietta F., Paulesu L., Miracco C., Cintorino M. \& Marcolongo R. (2003) Expression of macrophage migration inhibitory factor in diffuse systemic sclerosis. Annals of the Rheumatic Diseases 62, 460-464.

Shlomchik W.D., Couzens M.S., Tang C.B., McNiff J., Robert M.E., Liu J., Shlomchik M.J. \& Emerson S.G. (1999) Prevention of graft versus host disease by inactivation of host antigen-presenting cells. Science 285, 412-415.

Shulman H.M., Sullivan K.M., Weiden P.L., McDonald G.B., Striker G.E., Sale G.E., Hackman R., Tsoi M.S., Storb R. \& Thomas E.D. (1980) Chronic graft-versus-host syndrome in man. A long-term clinicopathologic study of 20 Seattle patients. The American Journal of Medicine 69, 204-217. 
Socie G., Stone J.V., Wingard J.R., Weisdorf D., Henslee-Downey P.J., Bredeson C., Cahn J.Y., Passweg J.R., Rowlings P.A., Schouten H.C., Kolb H.J. \& Klein J.P. (1999) Long-term survival and late deaths after allogeneic bone marrow transplantation. Late Effects Working
Committee of the International Bone Marrow Transplant Registry. New England Journal of Medicine 341, 14-21.

Toubai T., Tanaka J., Nishihira J., Ohkawara T., Hirate D., Kondo N., Tone S., Shono Y., Ibata M., Sugita J., Kato N., Miura Y., Iwao N., Ota S. \& Imamura
M. (2006) Effect of macrophage migration inhibitory factor (MIF) on acute graft-versus-host disease in a murine model of allogeneic stem cell transplantation. Transplant immunology 16, 117 124. 